\title{
Regional elections of 2020 in the Irkutsk region: progress, results, and organization
}

\begin{abstract}
The regular conduct of elections and the compliance of their procedure with the current legislation is a prerequisite for the functioning of a democratic political system. The occurrence of emergencies, such as military operations, pandemics, and the like, is a serious problem and challenge for the country's leadership. The resulting social tension and instability, changes in the current electoral order and electoral procedures, pose a threat to the ruling regime and provide additional opportunities for the opposition. The article shows the activities of the leadership of Russia and the Irkutsk region in the context of a Covid pandemic during the regional elections of 2020. The legislation was changed and special measures were organized to ensure compliance with all epidemiological norms and to prevent a significant increase in the number of cases. A special feature of the elections in the Irkutsk region was the holding of early, really competitive elections for the governor, in which a Kremlin protege and a local representative of the Communist Party fought. In a really difficult situation, the elections were held calmly and without any special violations of the law and moral norms. Despite the fundamental nature of the struggle for the governor's seat, the voter turnout was low and fundamentally lower than the plebiscite held in July of the same year to amend the Constitution of the Russian Federation.
\end{abstract}

Key words: regional elections in Russia, Irkutsk region, features of elections in the context of a pandemic, early elections of the governor

E lections in a democratic political system are the most procedurally prescribed element. The changes made to the election model have been discussed and agreed upon for a long time, cause a great public response, and therefore are an extraordinary event for the government and the population. It is another matter when extraordinary events occur in a country, and even more so in the world - a war or a pandemic. Such situations are extremely rare, so they always draw attention of political scientists. This article focuses on the analysis of a similar phenomenon: the elections in Russia and in the Irkutsk region in the "Covid" year 2020.

\section{Preparations for the elections}

The coronavirus pandemic posed more risks for the Russian government than for other political players. The main challenges for the Kremlin in 2020 could be attempts to impose a postponement of the vote, as well as pedaling the negative situation in the economy, leading to a deterioration in the well-being of citizens. At the same time, the decline in political activity and public interest in the elections, and, consequently, the decrease in turnout, played in its favor. It was also in the interests of the authorities that society agreed to strengthen the role of the state in emergency situations. The combina- 
tion of these factors have provided the Russian ruling class with opportunities to smooth out the negative political effects of the pandemic (Coronavirus, 2020).

This combination of problems and circumstances forced the Russian authorities to carefully monitor and analyze the changing domestic political situation in the country and respond to the multidirectional vectors that operated in it. The elections of September 2020 are the first elections after the coronavirus pause and the all-Russian vote on amendments to the Constitution of the Russian Federation (late June-1 July). Then, attempts to play on the powerful socio-economic blow to Russia caused by COVID-19, frankly failed: according to official data, $77.92 \%$ of those who came to the election (polling) booths supported the proposed amendments to the Constitution of the Russian Federation, with a turnout of $67.97 \%$ of registered voters. However, then the situation worsened: protests broke out in Khabarovsk (July 2020), an attempt to conduct a "color revolution" in Belarus developed, and the "poisoning" of blogger Navalny was exaggerated.

All these and other events, in addition to their specific goals, special in each case, had a common vector: the desire of the opposition to seize control of the internal Russian information agenda at any cost, to reduce the support of the federal government from the Russian society and split it. During these campaigns and after them, to push left and right, patriots and liberals, Russians and non-Russians, atheists and believers, Orthodox and Muslims, and so on. The question was put on the agenda: how strong will be the impact on the political landscape of Russia and its regions, this, far from random, common vector, and in which direction will there be shifts, if they do occur? The answer to these questions should have been given by the elections on September 13, 2020. Their results would largely determine the future actions of our foreign partners and their affiliated domestic politicalforces (Vinnikov, 2020).

In order not to "shake up" the domestic political situation, the head of the Russian Central Election Commission, E. A. Pamfilova, on April 3, suggested that the regional authorities postpone the holding of mass political campaigns scheduled for the period from April 5 to July 21, and, to declare a moratorium until the September elections on holding any mass political actions and events (Coronavirus, 2020).

On 13 May, 2020, the deputies of the State Duma of the Russian Federation adopted in the third and final reading a bill authorizing the holding of elections by mail and on the Internet. The amendments were due to the coronavirus pandemic and were introduced in order to organize the voting process in the regional elections in September (Sudden, 2020) In addition to them, in July the State Duma adopted a law allowing voting for three days in elections of any level. The election commissions were also instructed to ensure strict compliance with the new epidemiological requirements. The amendments to the electoral legislation adopted in spring allowed candidates to collect signatures through the portal "State Services." In the premises of polling stations, lines should be drawn on the floor indicating a safe distance between visitors, they should have been measured for temperature and provided with a sanitizer for voting participants (Kuznetsova, 2020). These features of the conduct of elections in the regions were brought to the attention of election commissions, voters, observers and representatives of the media, who are supposed to be at the polling stations during the elections (Recommendations, 2020). 
A number of analysts, assessing these innovations, believed that such a voting procedure would create difficulties for sociologists and candidate headquarters to predict the turnout and result of the elections, as well as to control their conduct.

The Russian authorities, due to the coronavirus pandemic, in order to protect the health of voters, for the first time moved away from the format of a single voting day and allowed local election commissions to hold elections within three days. 11 and $12 \mathrm{Sep}-$ tember were designated as additional days, and 13 September was designated as the main voting day (How, 2020). At the same time, the Complexes for processing ballots (COIB - abbreviation in Russian) were supposed to work at polling stations only on the main voting day of 13 September (The CEC, 2020).

Most of all, concerns about the three-day voting were raised by the issue of the safety of ballots at night. The Central Election Commission developed a special procedure: the completed forms were stored in safe bags with individual numbers and several degrees of protection. Observers should have been able to monitor the order of storage of documentation at all stages. Apart from a few incidents and curiosities, this system turned out to be quite reliable (Mislivskaya, 2020).

According to the Central Election Commission of the Russian Federation, more than 230 thousand representatives of various parties, social movements and the candidates themselves were supposed to observe the voting process and vote counting. In addition, around 22thousandobservers were registered as a reserve. According to the rules, one representative from an association or a candidate could be present at a stationary polling station. Another one could join the mobile commission to monitor the progress of the exit voting (The CEC, 2020).

The format of the upcoming elections was impressive, they were the largest in the history of the Russian electoral system. In 83 regions, there were more than 9 thousand campaigns of all levels, in most cases, voting took place not only on 13 September, but also on the previous days. It was supposed to replace more than 78 thousand deputy mandates and elected positions. Among them, there were elections of 18 governors, deputies of 11 regional parliaments and city dumas of 22 regional capitals, and 4 deputies of the State Duma. And the expression of will itself had to take place with the use of an unprecedented number of digital technologies (Mislivskaya, 2020).

Exactly half of the 18 regions, including the Irkutsk Region, were headed not by "permanent" (elected last time) governors, but by acting governors. For them, the postponement of the elections was not beneficial, since their incomplete status in this case was delayed. From a legal point of view, the governors elected last time after the expiration of their term of office and in the event of postponement of the elections, also had to be transferred to the status of acting temporarily (Kuznetsova, 2020).

In the Irkutsk Region, there were 89 election campaigns to be held on a Single voting day in 74 municipalities. There were election of 12 mayors, 35 heads of administrations, as well as deputies of municipal duma (42 campaigns) (The results, 2020).

The upcoming elections in the Irkutsk region also included the election of the governor, who was elected for a five-year term. They were declared early, as the governor S. G. Levchenko, whose powers expired in September 2020, prematurely resigned on 12 December, 2019. After that, Russian President Vladimir Putin appointed Deputy Head of the Ministry of Emergency Situations of Russia, Chief State Inspector of the 
Russian Federation for Fire Supervision I. I. Kobzev as acting Governor of the Irkutsk region.

Not willing to risk being elected from the United Russia party, on 20 May, 2020I. I. Kobzevsigned amendments to the law "On the Election of a Governor of the Irkutsk Region," which introduced the procedure for self-nomination of candidates. In the Irkutsk Region, candidates are nominated both by political parties and by self-nomination. A self-nominated candidate must collect $0.5 \%$ of the signatures of the electorate, i.e. about 9,300 signatures, in order to register. In the region, any candidate for a governor's office must collect the signatures of $5 \%$ of municipal deputies and heads of municipalities. Among them there must be signatures of deputies of district and city councils and (or) heads of districts and city districts in the amount of 5\% of their total number. In addition, the candidate must obtain signatures in at least three-quarters of the districts and city districts, that is, in 32 out of 42 .

In April 2020, ex-governor S. G. Levchenko said that he was going to participate in the elections on 13 September, but did not rule out that he would not be allowed to participate in the elections. When calling the gubernatorial elections in June 2020, the Legislative Assembly of the region declared them early, so Levchenko (in accordance with the law) could participate in them only with the permission of the president. Levchenko applied to President Putin for such permission only in mid-June 2020. Due to the uncertainty, the bureau of the Irkutsk Regional Committee of the Communist Party of the Russian Federation recommended to nominate the current deputy of the State Duma of the VII convocation and a member of the State Duma Commission on Support of small and Medium-sized Businesses M. V. Shchapov as a "reserve" candidate.

On July 29, the election Commission of the Irkutsk Region completed the acceptance of documents from candidates. Seven "self-nominated" candidates out of 15 declared candidates were unable to collect the signatures required for registration. 8 candidates continued to participate in the campaign. The decision on their registration was made by the election commission within ten days from the date of submission of the documents after checking the support sheets, signatures, as well as the information specified by the candidate. On 14 August, the representative of the Civic Platform party G. Vakulenko and the candidate of the Rodina party M. Evdokimov (Elections, 2020) announced the termination of participation in the election campaign. As a result, there were five candidates for the post of governor of the region.

\section{Election progress}

The elections in the Russian Federation, including in the Irkutsk region, were held without any special incidents and violations. The Election Commission of the Irkutsk region on 17 September summed up the final results of the regional elections. I. I. Kobzevwas elected Governor of the region, gaining $60.79 \%$ or 369,759 votes cast with $1,861,205$ registered voters. His main competitor, M. V. Shchapov, received the support of $25.50 \%$ or 155,066 voters (Elections, 2020). For the first time, the United Russia party did not invite technologists from other regions to promote candidates, but conducted an election campaign on its own (Eight, 2020). 
12 mayors were elected in the region, 8 of which were representatives of the United Russia party (The results, 2020). The United Russia party won a landslide victory in the opposition Irkutsk region, providing one of the best results in Russia (Sergey, 2020). At the same time, the Irkutsk region again showed one of the lowest turnouts in the country, but this result is correct to compare not with the regions where the elections have long been reduced to a formal procedure for approving the necessary candidates in the spirit of the late USSR, but with previous electoral cycles in the Irkutsk region itself: In 2015, 545 thousand voters came to the first round of gubernatorial elections (turnout of $29.2 \%$ ). In $2018,1,045$ thousand voters $(55.7 \%)$ came to the presidential election. In 2020, 824 thousand people (44.1\%) came to the weekly constitutional "plebiscite." And 600 thousand people (32\%) came to the governor's election in 2020. That is, before the federal campaigns, the turnout in 2020 is far short, but at the same time it exceeds the indicator of the first round of similar elections five years ago. At first glance, the difference of 3\% and 55 thousand votes does not seem significant, but here we must take into account that the current elections were held for three days. Without this, the final turnout would hardly have reached even $25 \%$. In other words, the mobilization effect of the three-day period worked (Fedorov, 2020).

For residents of the Irkutsk region, the struggle in the elections and the constant change of governors is something natural, to which they have long been accustomed. However, if we look more broadly, "measuring the average temperature in the hospital," we will see that the current election campaign in the Angara region was perhaps the most interesting, competitive and unpredictable in the country. In no other region has the Kremlin's candidate been forced to run a full-fledged campaign and promise something to the voters. It sounds ridiculous, but in the Russian "swamp" and it pulls on the achievement.

The Irkutsk elections held an intrigue until the last moment and in this sense were similar to a full-fledged democratic show in the Western tradition. The candidate from the Communist Party of the Russian Federation, M. V. Shchapov, conducted a smart, stylish, one might say, intelligent campaign, very European, very pleasant. But this was not enough to transfer the elections to the ground floor, that is, to the second round. And there was not enough time, money and healthy political aggression. Shchapov worked on the positive and did not "pump" the protest at all, and it was the protest vote that was (and remains) the main resource of the opposition in the Russian elections. Shchapov started the campaign in July, and Kobzev-in December, and here it is important to point out the serious organizational failure of the Communist Party, where for some reason for six months they unwound the obviously doomed story "Levchenko goes for a second term," instead of investing in Shchapov-objectively the most promising and resource-rich candidate of the current communist party.

Modern political history shows that the opposition's electoral victories in the Baikal region have always been accompanied by a split in the local elites. So it was in 2010 (the election of the mayor of Irkutsk), in 2015 (the election of the governor), in 2018 (the election to the Legislative Assembly). On the other hand, when elites find balance and mutual understanding, electoral revolt becomes something inappropriate and even burdensome. So it was in 2013 (elections to the Legislative Assembly), in 2016 (elections to the State Duma), and so it is now, in 2020, in the election of the governor. But political 
history also transparently hints that any consolidation of elites in the Irkutsk latitudes does not last very long and almost inevitably turns into a new war of all with all. So we will observe-the "candy-bouquet period" of Governor Kobzev lasts from December 2019, and there is no reason to think that this fuse will last for the entire five-year term (Fedorov, 2020).

The election campaign in the Irkutsk region, its turnout and results were influenced by two main factors. The first is the fatigue of the electorate from any pre-election processes in principle. This year's election of the governor is the second serious vote in the Angara region, the first was the vote on amendments to the Constitution of the Russian Federation. They both passed in the coronavirus mode, which also had a serious and complex impact on the population. To ensure the safety of the residents, the voting went on for several days. Many thought that this would affect the turnout, that the candidates would be able to further mobilize their voters. However, the number of voters in 2020, in comparison with 2015, did not increase much. However, it doesn't make much sense to evaluate the current turnout and compare it with the previous elections, because in 2015, there was also a serious competitive campaign, but it took place in completely different conditions (Why, 2020).

\section{Election results}

The main result of the September 2020 vote in Russia - there were no sensations. The current heads of the executive power did not lose in any of the regions. Candidates from the United Russia party also entered the State Duma. This is evidence that the number of citizens who trust the president of Russia and vote in his favor has not decreased over the past two months, after the plebiscite.

The analysis of the elections held in the Russian Federation shows that the turnout, despite the introduction of the "three - day period," that is, the early expression of the will of voters during Friday and Saturday, 11-12 September, in addition to the main Sunday, 13 September, compared with the "constitutional" vote of 25 June-1 July, significantly decreased. This can be explained by the "local" nature of the 13 September elections, but the difference is such that the conclusion is clear: Russian society as a whole, and especially in certain regions of the country, is showing increasing political passivity or, in other words, calmness, and this is less true of the national subjects of the Federation.

As of today, none of the opposition or alternative political structures - whether parliamentary, extra-parliamentary, old, new, pro-Russian, or pro-Western-in general enjoys any significant trust from Russian voters, and can not boast of a noticeable increase in trust, getting past the objective political agenda. As a result, a very significant political "no man's land" is being formed, which, in theory, can become an electoral base for some "new opposition," and already by the parliamentary elections of 2021 (Vinnikov, 2020).

According to experts, the 2020 gubernatorial elections in the Irkutsk region were more difficult than any other, as they were held in three days. This created a serious burden, both on the election commissions and on the headquarters of the two main candidates who were fighting for the governor's seat. Observers from M. V. Shchapov, I. I. Kobzev and the Public Chamber of the Irkutsk Region were present at the polling stations. The 
presence of observers and the operational work with the headquarters showed that all the issues related to the early voting on Friday and Saturday, and the main voting day, were resolved during the election process. There were no serious violations, the elections are completely legal (Why, 2020).

The Kremlin's henchman, I. I. Kobzev, has been campaigning continuously since December 2019. According to the most conservative estimates, at least a billion rubles were invested in his PR and the work of his technical candidates, and this is not counting the resources of the Irkutsk region budget, which were thrown into the fulfillment of Kobzev's numerous and very expensive promises. The electoral legislation was specially changed for him, freeing him from the encumbrances of the anti-rating of the United Russia party. The mayor of Bodaibo, Ye. Yu. Yumashev, was removed from the election. Yumashev, popular in the municipal environment, but the obvious spoiler G. I. Shchadov was included in the lists of candidates. The support for Kobzev was shown by federal ministers and President Putin (Fedorov, 2020).

The organization of the September 2020 elections was evaluated differently by the authorities, the opposition and the population. According to the opposition mass media, the main problems during the voting days were violations related to the procedure for conducting early voting (violation of the rules for storing ballots from early voting, refusal to provide information about the number of voters and to familiarize themselves with the acts of early voting, violation of the integrity of safe packages, late preparation of these acts), violations when voting outside the voting premises (mass registration of voters in the relevant register against their will), violations in the counting of votes (simultaneous counting of votes in several bundles of ballots, non-public counting of votes, simultaneous implementation of several stages of counting votes, failure to conduct the final meeting of the precinct commission) ("The worst, 2020).

In a number of regions and districts, the fight against the epidemic has actually turned into a tool to restrict the voting rights of citizens. Under its pretext, the possibilities for conducting election campaigning were limited (first of all, the campaigning of opposition parties and candidates), and the candidates and headquarters were pressured by law enforcement agencies. The epidemiological situation has led to the introduction of "new" forms of voting that make it as difficult as possible for society to control them. During the voting days, individual election commission chairmen used the epidemiological situation as a cover to restrict the rights of public supervisors. Objectively, the "new forms" of voting significantly reduced the possibility of public control over the work of election commissions, made it much more resource-intensive. The number of observers required for real control of the voting process has increased at least 3-4 times (and taking into account the fact that early voting is accompanied by mass voting outside the premises of precinct election commissions) and even more (How, 2020).

At the same time, there is no doubt that the majority of voters who came to the elections supported the representatives of the United Russia party, the absolute majority of the polled voters approved the possibility of voting within a few days - this opinion is shared by $64 \%$ of all participants in the VTsIOM poll and $72 \%$ of those who took part in the vote. An important and new phenomenon on election day was experiments with promising election technologies - electronic remote voting, technical means for counting votes and processing ballots, as well as video surveillance (Anufrieva, 2020). 


\section{Conclusion}

Thus, the autumn 2020 elections in Russia, including in the Irkutsk region, which took place at the height of the pandemic, revealed a number of facts and trends. First of all, the fact that state and public institutions were able to organize the election process effectively and within the framework of the current legislation. This is a testament to the country's high degree of governance. During the voting in Russia as a whole, and in the Irkutsk region in particular, the representatives of the United Russia party won. At the same time, the turnout for the elections was low, which indicates a great opportunity for the potential opposition. However, as of September 2020, there was no such party in the Russian Federation. It must be recognized that the introduction of emergency measures due to the epidemiological situation was used by a number of officials to violate the electoral procedure. In addition, the fact that even the unprecedented use of IT technologies used to control elections did not allow us to avoid individual cases of their violation and falsification of voting results.

\section{Bibliography}

Anufrieva K. (2020), Published a report on the results of the Unified Voting Day on September 13, 2020, "Komsomolskaya Pravda", 25.09.2020, https://www.kp.ru/online/news/4025789/.

Coronavirus vs Single Voting Day: what risks did experts point out, https://politsib.ru/news/37615-koronavirus-vs-edinyj-den-golosovania-na-kakie-riski-ukazali-eksperty, April 07, 2021.

Eight candidates from "United Russia" won the election of mayors of municipalities of the Irkutsk region, https://www.irk.ru/news/20200914/vote/?utm_source=yxnews\&utm_medium, April 17, 2021.

Election of the Governor of the Irkutsk region, https://ru.wikipedia.org/wiki/\%D0\%92\%D1\%8B$\% \mathrm{D} 0 \% \mathrm{~B} 1 \% \mathrm{D} 0 \% \mathrm{BE} \% \mathrm{D} 1 \% 80 \% \mathrm{D} 1 \% 8 \mathrm{~B} \_\mathrm{0} 0 \% \mathrm{~B} 3 \% \mathrm{D} 1 \% 83 \% \mathrm{D} 0 \% \mathrm{~B} 1 \% \mathrm{D} 0 \% \mathrm{~B} 5 \% \mathrm{D} 1 \% 80$ $\% \mathrm{D} 0 \% \mathrm{BD} \% \mathrm{D} 0 \% \mathrm{~B} 0 \% \mathrm{D} 1 \% 82 \% \mathrm{D} 0 \% \mathrm{BE} \% \mathrm{D} 1 \% 80 \% \mathrm{D} 0 \% \mathrm{~B} 0 \% \mathrm{D} 0 \% 98 \% \mathrm{D} 1 \% 80 \% \mathrm{D} 0 \% \mathrm{BA}$ $\% \mathrm{D} 1 \% 83 \% \mathrm{D} 1 \% 82 \% \mathrm{D} 1 \% 81 \% \mathrm{D} 0 \% \mathrm{BA} \% \mathrm{D} 0 \% \mathrm{BE} \% \mathrm{D} 0 \% \mathrm{~B} 9 \% \mathrm{O} 0 \% \mathrm{BE} \% \mathrm{D} 0 \% \mathrm{~B} 1 \% \mathrm{D} 0 \% \mathrm{~B}-$ B\%D0\%B0\%D1\%81\%D1\%82\%D0\%B8_(2020), May 16, 2021.

Fedorov L. (2020), Election of the Irkutsk governor. Figures and conclusions, https://www.babr24.com/ irk/?IDE=204899, May 19, 2921.

How was the single voting day-2020, https://tass.ru/politika/9428017, April 14, 2021.

Kuznetsova E. (2020), The first elections in Russia during the pandemic, https://www.rbc.ru/politics/14/09/2020/5f5b817b9a79470e4816cc6b, May 18, 2021.

Mislivskaya G. (2020), Selective Approach, "Rossiyskaya Gazeta - Stolichny Issue", no. 205(8259), September 13, 2020, https://rg.ru/2020/09/13/v-rossii-proshel-edinyj-den-golosovaniia.html.

Recommendations to election commissions, voting participants, observers and media representatives on the prevention of risks associated with the spread of coronavirus infection (COVID-19) in the preparation and conduct of a single voting day on September 13, 2020, http://02.rospotrebnadzor.ru/content/228/39405/, May 11, 2021.

Sergey Sokol: in the last elections in the Irkutsk region, United Russia won a landslide victory, https:// i38.ru/kommentariy-politika/sergey-sokol-na-proshedshich-viborach-v-irkutskoy-oblasti-edinaya-rossiya-oderzhala-uverennuiu-pobedu?utm_source=yxnews\&utm_medium=desktop, May 18, 2021.

Sudden amendments: the State Duma adopted a bill on voting by mail and via the Internet, https:// tv2.today/News/Vnezapnye-popravki-v-gosdume-prinyali-zakonoproekt-o-golosovanii-popochte-i-cherez-internet, May 25, 2021. 
The CEC announced a three-day vote in the September elections, https://tass.ru/obschestvo/9043523, April 24, 2021.

The results of the municipal elections in the Angara region were published, https://regnum.ru/news/ polit/3062450.html, May 15, 2021.

The results of the municipal elections in the Angara region were published, https://regnum.ru/news/ polit/3062450.html, May 23, 2021.

"The worst in the last 25 years": Golos activists rated the elections on September 13, "NovyeIzvestia", 16.10.2020, https://newizv.ru/article/general/16-10-2020/hudshie-za-poslednie-25-let-aktivisty-golosa-otsenili-vybory-13-sentyabrya.

Vinnikov V. (2020), The elections of September 13 turned into a political victory for Russia over the coronavirus, https://riafan.ru/1311489-vybory-13-sentyabrya-obernulis-politicheskoi-pobedoi-rossii-nad-koronavirusom, May 16, 2021.

Why did Shchapov lose and Kobzev win? Experts comment on the results of the election of the governor of the Irkutsk region-2020, https://irkutsk.bezformata.com/listnews/viborov-gubernatora-irkutskoy-oblasti/ 87205978/ 15.09.2020, May 23, 2021.

\section{Wybory roku 2020 w obwodzie irkuckim: przebieg, wyniki i organizacja}

\section{Streszczenie}

Regularne przeprowadzanie wyborów i zgodność ich procedury z obowiązującym ustawodawstwem jest warunkiem funkcjonowania demokratycznego systemu politycznego. Występowanie sytuacji nadzwyczajnych, takich jak operacje wojskowe, pandemie i tym podobne, stanowi poważny problem i wyzwanie dla kierownictwa państwa. Wynikające z tego napięcia społeczne i niestabilność, zmiany w dotychczasowym porządku i procedurach wyborczych, stanowią zagrożenie dla rządzącego reżimu i stwarzają dodatkowe możliwości dla opozycji. W artykule przedstawiono działania kierownictwa Rosji i obwodu irkuckiego w kontekście pandemii Covid podczas wyborów regionalnych w 2020 roku. Zmieniono ustawodawstwo i zorganizowano specjalne środki, aby zapewnić przestrzeganie wszystkich norm epidemiologicznych i zapobiec znacznemu wzrostowi liczby zachorowań. Szczególną cechą wyborów w obwodzie irkuckim było przeprowadzenie przedterminowych, naprawdę konkurencyjnych wyborów gubernatora, w których walczyli protegowany Kremla i lokalny przedstawiciel partii komunistycznej. W naprawdę trudnej sytuacji wybory odbyły się spokojnie, bez szczególnych naruszeń prawa i norm moralnych. Mimo fundamentalnego charakteru walki o fotel gubernatora, frekwencja wyborcza była niska i zasadniczo niższa od przeprowadzonego w lipcu tego samego roku plebiscytu w sprawie zmiany Konstytucji Federacji Rosyjskiej.

Słowa kluczowe: wybory regionalne w Rosji, obwód irkucki, cechy wyborów w kontekście pandemii, przedterminowe wybory gubernatora 
